\title{
Implementation of School-Based Management Towards Peace Building and Child Protection
}

\author{
Agustinus Hermino \\ Basic Secondary Education Program in West Papua \\ Indonesia \\ agustinus_hermino@yahoo.com; agustinus.hermino@bsep.or.id
}

\begin{abstract}
The purpose of this research is to describe about implementation of school-based management in three pillars towards peace building and child protection in primary schools in the District Jayawijaya, Central Mountains Papua. The research method applied is qualitative research with content analysis approach were used to identify opinions and perceptions of implementation school-based management. Result of the study showed: (1) lack of parenting in the family makes children cannot learn as well, because at home they have to work or help parents in the garden. Especially in the season open the gardens, children cannot go to school because they have to help parents; (2) general community still do not understand about role of the school committee so that a sense of ownership of the school and community responsibility for the continuity of education in the region have not been so strong; and (3) joyful learning is a new concept that is a little difficult to be accepted by the teacher because because most children will understand their responsibility as students when teachers through teaching commensurate with the conditions of the region. Based on these conditions, strong leadership and contextual understanding really important to develop peacebuilding and child protection for the successful implementation of school-based management
\end{abstract}

Keywords-school-based management, peace building, child protection

\section{INTRODUCTION}

Blessed with abundant natural resources and fertile soil, the Papua's Central Mountains has an important role in determining the success of development in Papua province in particular and Indonesia in general. As migrants from other parts of the country have flocked to the Central Mountains, the ratio between the natives is now well balanced. Ironically, the migrants have dominated the business and economy sectors as well as job opportunities, while the native Papuans become marginalized and lost their customary lands acquired by companies who wish to expand their agribusinesses. The native Papuans now become farm workers on their ancestral land that belonged to them for thousand years.

As stated in the Jayawijaya Statistic Agency, year 2014 that Jayawijaya regency consists of 40 districts, 328 villages and 4 sub-districts with a total area of $13.925,31 \mathrm{~km}^{2}$. According to the Jayawijaya Statistics Agency, the total population in Jayawijaya regency in the mid-2013 stood at 203.085 people with 99,512 females and 103.573 males.
Jayawijaya regency was developed based on Law No. 12 1969 with its capital Wamena. Jayawijaya regency borders with regencies of Lanny Jaya, Tolikara, Central Mamberamo in the west; Yahukimo and Yalimo in the East; Nduga and Yahukimo in the South; and Central Mamberamo and Yalimo in the North.

Lanny Jaya regency was developed from Jayawijaya regency, which consists of 10 districts namely Tiom, Pirime, Makki, Gamelia, Dimba, Tiomneri, Melagineri, Balingga, Kuyawage and Poga. Lanny Jaya regency has the total area of $\pm 2.248 \mathrm{~km}^{2}$ with its capital Tiom. The regency borders with Tolikara regency in the north, Nduga regency in the south, Jayawijaya regency in the east and the western part borders with Puncak Jaya regency. According to 2010 census, which stated in the Papua Statistic Agency, year 2015 that the total population in Lanny Jaya was 148.522 people with 79.691 males and 68.831 females.

In terms of security, Papua has experienced conflict far before the transition to democracy. Beside horizontal conflict between Papuans, vertical conflict between the natives and Indonesian government is obvious as the demand for referendum and freedom has caused many victims. Security measure in Papua has caused many problems, including human rights violations in several areas.

From the different perspective, the conflicts in Papua may have been the outcome of injustice system derived from unequal distribution of economic development under the New Order regime. The unequal distribution process of the economic development had become institutionalized and an effort of structured and permanent impoverishment [1]. As parts of Papua, the security conditions in Jayawijaya and Lanny Jaya regencies are still prone to conflicts.

The education system in Papua's Central Mountains first implemented in 1950 s by individual missionary or groups backed by various churches. These missionaries learned the native languages and translated the bibles into those languages. Literacy is a tool to spread the bible. Missionaries have implement basic tradition of education in several areas such as Piramida and Ninia until today. They established schools in Wamena and Sentani that become one of the best schools in Papua.

Stated in the Papua Statistical Agency, year 2015, that the Dutch colonialist admitted their inability to educate the Central Mountains natives and therefore asked the church to 
implement education system, they also disbursed the fund through the church to pay salary for the teachers. They used Dutch language as medium before Indonesian language become mandatory after 1962. Then Biblical Church Education and School Foundation (YPPGI) were established to ensure that the system met the education standard.

In 1980s, the Indonesian government took over the education system. The health care system of missionaries was also taken over by the government, giving chances for the church to focus on their initial task - to spread the bible, and at the same time, their authority in Papua declined as they handed over their social role. Teachers become civil servant and schools adopted education system implemented by the colonialist as national curriculum. However, the government did not fully taking over as there were no systematic mechanism and comprehensive partnerships between foundations that operates most of schools in Papua.

The failure of transition system became obvious in Central Mountains since 2000, when there were mass killings against dozens of non-Papuan civil servant that triggered massive exodus in the area - most of them were medical and educational staff [2]. The term 'Papuanization' emerged and occurred in massive scale within the governance, where the natives took the posts within the government as an act of affirmatively, not mandatorily; they have no competences but claimed their positions based on clan affiliations. It has negative impact to the established regencies. However, the newly developed regencies suffered worst impact, the education service collapsed.

\section{OBJECTIVES AND SCOPE OF THE RESEARCH}

\section{A. Objectives of the Research}

The research is carried out at 12 elemantary schools; consist 9 schools in Jayawijaya regency with its capital Wamena situated in Baliem Valley, those schools are: (1) YPPK Honelama; (2) YPPK Hepuba; (3) YPPGI Anigou; (4) Inpres Wesaput; (5) Inpres Air Garam; (6) Advent Maima; (7) Inpres Wame; (8) YPPK Assologaima; (9) YPPGI Tulem; and 3 schools in Lanny Jaya regency with its capital Tiom, those schools are: (1) Inpres Tiom; (2) Inpres Indawa; (3) YPPGI Tobanapme. Those two districts are prone to conflict situations that affect learning process, especially at those 12 schools studied.

The objectives of this research is in order to get understanding about society which capable to provide safe and peaceful environment for girls and boys development in the primary schools especially during an implementation of school-based management in the Dstrict of Jayawijaya and Lanny Jaya, Papua, Indonesia.

\section{B. Scope of the Research}

There are three significances of the research: (1) peace building and child protection mainstreaming at the primary schools. This case will be examined regarding developing school curriculum that integrates values and principal of local wisdom as part of daily teaching and learning process; (2) social empowerment to develop peace building and child protection. The main goal is to raise awareness of local leaders about the importance of safe and peaceful environment for the child development and growth; and (3) improvement of government policy to foster peace and child protection. The result is expected to improve the capacity and commitment of local government to support and promote peace and child protection through regional law.

\section{RESEARCH METHODOLOGY}

This research used the qualitative method, which are vontained thinhs to be assessed: first, about parent, such as: a) social-economy and demography, including household characteristics in 9 villages in Jayawijaya regency and 3 villages in Lanny Jaya regency involved in the survey, namely: age, sex, number of children at home, education and occupation; b) parent's knowledge, attitude and behavior toward safe environment for children; c) parent's aspiration and perception toward child education.

Second, about school, such as: a) school profile related to education quality, including number of students that meets school competence standard, number of certified teachers, number teacher task group; b) school-based management implementation, including factors related to the achievement to implement SBM and students' accomplishment; c) performance of principal, teachers and school committee to lead and develop programs suitable for local residents; d) performance of teacher during teaching and studying process in classrooms; e) students' experience against mistreatment and violence from the environment including parents, teachers and friends; f) school programs, local curriculum and modules to support implementation of peace and child protection education.

Third, about community and government, such as: a) aspiration and perception of community against education quality at schools and Peace building and child protection mainstreaming; b) initiative development community programs that mainstreaming Peace building and child protection; c) partnership programs between community and government; d) existing regional government policy and regulation to support the implementation of Peace building and child protection; e) violence rate case occurred in two regencies (Jayawijaya and Lanny Jaya regencies).

\section{FINDINGS \\ A. Peace Building and Child Protection Mainstreaming at the Primary Schools}

Child-friendly school environment is a basic thing needed to ensure that learning process runs according to the academic plan during certain period. The smoothness of learning and teaching process at school shown from several factors, such as: (1) principals and teachers attendance rate; (2) students' active involvement during learning and teaching process; and (3) the availability of learning facilities and infrastructures such as tables, chairs and textbooks.

At the Advent Maima elementary school, the principal is punctual. The commitment is followed by other teachers resulting in higher disciplinary level. Students are actively 
involved in several activities according to project-based learning that can be seen through crafts made by students.

At the YPPK Honelama elementary school has high disciplinary level. Principal and teachers usually discuss the constraints and challenges with parents and local leaders to find the best solutions. Variety of student activities during learning and teaching process as well as student group activities at noon can be a good example for other targeted school.

At the Inpres Tiom elementary school has a principal with high commitment to ensure that learning and teaching process is implemented although the school is located in conflictprone area. Support of Graduate Teaching in Remote Area Program (GTRAP) and honorary teachers have contributed to good quality of learning and teaching process.

Several elemantary schools have also showed similar actions such as YPPGI Anigou elementary school with sufficient number of teachers that started to implement AJEL (Active Joyful Effective Learning) learning method as well as YPPK Hepuba elementary school with variety of class displays made by teachers and students.

\section{Violence Against children}

Based on discussion and interview with parents, teachers and local leaders, research team concluded that the significant decrease of physical, verbal and psychological violence is a direct impact of child rights protection campaign and legal consequences that may arise from the violation. The campaign conducted by project has the benefit at knowledge level. When the knowledge level of adults is escalated, it is not automatically changed their behavior and/or skills towards better condition. The main obstacle that hampers behavioral change within all school interventions is rooted in the strong perception that punishment is a form of caring, and is not a form of violence. Parents and teachers as the dominant subjects of violence are lack of better disciplinary actions to deal with children.

\section{Inconsistency in the implementation of School-Based Management (SBM)}

Generally, schools have yet to implement SBM with its three pillars, such as: school management, joyful learning, and community participation. From 4 schools that have implemented SBM, researchers found that only 3 schools have implemented the approach, namely elementary school: Advent Maima, YPPK Honelama and Inpres Tiom as the principals have strong leadership, while in the YPPGI Anigou elementary schoo, principal plays dominant role in implementing operational programs, resulting in internal conflict with teachers and staff.

Interesting findings based on interviews and group discussions with school principals and teachers showed that trainings conducted by agency staff and NGO gave better knowledge and perception to implement school management principle to improve learning and teaching process. Direct practice to compose school work program plan and budget draft as well as stakeholder accountability report has yet to be optimized due to mentoring and monitoring limitation in all targeted school.

Several schools that 'tend' to be more successful to implement SBM are those, which have exemplary school principals with strong commitment. While schools that lack of capability and commitment failed to implement SBM such as elementary school: Inpres Wame, Inpres Indawa and YPPGI Tobanapme.

Such trainings have sparked initiative and determination to implement SBM three main pillars at schools. The Inpres Wesaput elementary school has implemented SBM but it has not been consistent due to teacher shortage and lack of parents' involvement.

The YPPK Honelama elementary school has implemented financial transparency by drafting school budget together with related staff. Similarly, Advent Maima elementary school's principal has also implemented the principle of openness although it is still being hampered by the lack of parents' involvement to improve learning process quality.

Achievement indicator stated in prodoc is "there are SBM model schools that mainstream peace building and child protection" has yet to be obtained due to lack of disciplinary, commitment, and awareness, coupled with low monitoring from related agencies.

\section{Incidental implementation of Teacher Working Group (TWG)}

According to a group discussions with teacher respondents, 7 out of 12 school interventions have yet to implement TWG activities during even semester of 2014/2015 academic term. Wesaput Inpress and YPPGI Anigou elementary schools said that they held regular meetings last year. The meeting agenda mostly discussed administrative things such as framing the lesson plan, formulating exam questions and Curriculum-2013 technical implementation.

Some TWG staff are newly formed at several primary schools, with their official working permits still being supervised. Advent Maima elementary school argued that TWG mini activity has more benefits than TWG at higher level as it was difficult to be implemented.

Schools have high level of external dependencies. The Inpres Wesaput elementary school only carried out TWG activity if being assisted by NGO team. Only YPPK Honelama elementary school that still held regular Principal Working Group (PWG) meeting twice a week with various agenda including formulating lesson plan, syllabus, teaching methods and character values.

\section{Local content student activity initiative}

Education in the Central Mountains of Papua cannot be separated from local context. Thus, the application national curriculum is inappropriate as it failed to interpret local wisdom and context.

Peace education and child protection has ignited and encouraged learning process at schools to use local resources, culture and wisdom that have been internalized within the community. Several schools have displayed posters to 
promote educational values. Teachers at the YPPGI Hepuba elementary school taught the values of local culture 'Pakima Hani Hano or harmony in unity' by giving students lesson on how to craft Noken (traditional bag) and arrow. Fifth grade students at the Inpres Tiom elementary were taught to make replica of Honai (traditional house), while the elementary school YPPK St. Yakobus students practice Papuan traditional dance and songs after class.

The initiative needs to be raised and addressed through indepth discussion on traditional values and culture before being developed and integrated with peace building and child protection into school curriculum. Principals and teachers at the elementary schools: Advent Maima and Inpres Air Garam have started to develop curriculum with local content using regional context approach.

\section{B. Social Empowerment to Develop Peace Building and Child Protection}

In the course of history, communal conflict in Papua's Baliem Valley is a symbol of manhood and strength. Dani, one of the most notorious tribes in Papua that inhabited the valley, is a wise, friendly and warm tribe. Dani tribe determined their leaders through communal conflict. The war is more of spiritual way rather than as a mean to settle a dispute. As the tradition shifted, the meaning of communal war has changed as a tool to seize power as well as to settle a conflict.

Central Mountains tribesmen grow up with the tradition of characterization. Tribal chief and clan elders are respectable, as they are considered capable to lead Papuans. The shift in the meaning of conflict was exacerbated by the 'bloody' annexation by the Indonesian government. The loss of trust in tribal chief and elders has the negative impact on the younger generation in Central Mountains.

\section{Improved public involvement through school committee}

School committee functions as important partner in order to improve learning quality at schools. The elementary schools: Advent Maima and YPPK Honelama school committee have been operating well, in which they already have simple work plan and program as well as proactively involved in the quest to improve quality of learning process.

School management committee have been established in the first semester in 4 schools, namely elementary school: YPPK Assologaima, Inpres Wame, YPPGI Tulem and Inpres Tobanapme. Although official letter has yet to be issued, the school committee have carried out various activities aim to improve the security at schools including building school gates, toilet renovation as well as to ensure that Principals and teachers attend the class. The Inpress Wame elementary school committee even urged the principal and teachers perform their tasks and responsibilities.

\section{Child-Friendly Village Initiative}

The applicable law within community is usually unwritten. While there is no applicable law that specifically address child protection issue, some communities uphold unwritten law to support schools to implement teaching and learning process.

Local institutions and leaders also conduct variety of campaign to raise awareness among communities on the importance of peace building and child protection. Some community leaders in the Baliem Valley resident, documented variety of folklores and traditional children's games to revitalize values, tradition and culture. Some religion leader also established a Honai (traditional house) as a community center completed with mini library. Some head of education community, advocate for better education and urges the government and related institutions to take firm action and control to ensure children's rights for education.

\section{Importance of religious values and culture awareness at school}

The role of church and local leaders is important to achieve project indicator target. All organizational and individual respondents have very well understandings on customs, culture and Papuan local context.

One of the supporting factors in implementing conducive learning process at the elementary school: Advent Maima, YPPK Hepuba and Inpres Tiom are the presence of local church members that involved. Several locations visited by the team have Honai functioned as learning center.

Most of targeted schools are run by religion-based education foundations such as Advent Education Foundation by Advent church, Biblical Church Education and School Foundation (YPPGI) by the Protestant Churches, and Catholic Education and School Foundation (YPPK) by the Roman Catholic Church. Papua Special Autonomy Law No.21/2001 has accommodated the foundations as the main partners to provide education in Papua.

Several foundations representatives expressed their concerns on how the political condition in Papua had caused shift in traditional value that directly undermine the quality of learning process. Foundations representatives stated they have smaller role in implementing school programs, resulting in the lack of quality control on learning process.

\section{Student group reinforcement}

Local leaders, educators and culture experts agreed that education in Papua's Central Mountains should return to local context. The issue however lies on Indonesian national curriculum - KTSP or K 13 that stresses on one size fits all concepts. Dealing with Papua is about pluralism. Papuan children grow in Multilanguage environment with complex geographic condition, and even the children have different physical characteristics.

The curriculum requirement has become some kind of scourge for various reasons. The advantage of KTSP and K 13 is freedom for schools to develop their local characteristics through formal and informal activities, including local content subjects and extracurricular. Unfortunately the local administrations have yet to manifest it as part practical curriculum at schools. 
There is a significant decline of student group activities, which there are 10 active student groups that uphold peace building and child protection mainstreaming. While based on field data, only 2 student groups that consistently implemented extracurricular or other related activities. The elementary school: Inpres Wesaput and YPPK Honelama have consistently implemented student group activities with peace building and child protection content. While at the Inpres Wame elementary school, the student group only play football. Several other primary schools have occasionally organized student group activities. This year, however, the aforementioned schools do not hold student group activities anymore.

Generally, the achievement in this segment is mostly effective, thanks to the initiative and consistent involvement of local leaders. However, students groups still need to be maintained as only 2 out of 12 student group targets that have routine activities

\section{Improvement of Government Policy to Foster Peace and Child Protection}

Presidential Regulation No.65/2011 on acceleration of development in Papua and West Papua opens the possibility for regional administration to issue regulations to fulfill the needs of native Papuans, especially in remote areas such as Central Mountains. The regional administration along with the Regional House of Representatives issued regulation No.56/2012 on the Procurement of Basic Education for Native Papuans or Remote Communities that emphasized on responsibilities and rights of the government at all levels to serve and community - including NGO, education foundation and private sector - to participate in the procurement of educational service. The Presidential Regulations assesses the native Papuans live in remote areas while special regulation emphasizes on Papuan language and local culture.

\section{Child-Friendly School (CFS)}

Cooperation between education agency, society and religion-based organizations is needed in order to build strong foundation in education. This cooperation is expected to improve the capacity of educators to cultivate a commitment to develop and formulate ideas as well as practical solution and contextual to improve the quality of education in Papua, especially in Central Mountains.

CFS is an education unit capable to guarantee, provide and respect the child rights protection against violence, discrimination and violence, as well as to bolster children participation in planning, policy, and study and complaints mechanism. CFS is one of the indicators of Child-Friendly City (CFC) as stipulated in Ministerial Regulation of Women Empowerment and Child Protection Ministry Number 12/ 2011 Article 11.

Several parents said during a discussion with the researcher that they have been aware of Law no.35 2014 on Child Protection through socialization conducted by project team during National Child Day commemoration or workshops at each school intervention project. If their children experienced violence at schools, they will not hesitate to address the issue directly to teachers and Principals.

\section{Government involvement in the Peace Education and Child Protection}

Both districts Jayawijaya and Lanny Jaya education agencies have welcomed the Peace Education and Child Protection, and wished for regular activities. The education agencies have also conducted re-organization by taking stern action against Principals absenteeism. Jayawijaya primary school division head said the agency has regularly summoned principals who are absent during term time and issued warning letters.

While in Lanny Jaya regency, the program activities were directly involved in several agency programs such as literacy and numeracy survey, teacher competency test, training and teacher's competence development that will be conducted in collaboration with related institutions. Education agency representatives were also involved in several activities including formation meeting and school committee discussion as well as teachers workshops.

Both districts Jayawijaya and Lanny Jaya also focuses on the development of teachers' quality in a bid to improve learning process. Several development programs including workshops, training and teacher transfer will soon be implemented. Through coordination and advocacy, Lanny Jaya education agency has been planned to be involved in the deliberation of regulation on Education System, and also build partnership with social institution and organization that have the capacity and education awareness is a top priority. This cooperation is expected to support agency's strategic plan to improve the capacity and performance of its staff. Education agency expects the formation of official forum at minimum, that capable of seeking solution and best alternative of the most suitable education model in Papua's Central Mountains.

\section{DISCUSSIONS}

Based on the research findins then will be discussed as follow:

\section{A. Transformational School Leadersip in the Perspective of School-Based Management}

Several studies conducted by previous researchers $[3] ;[4] ;[5] ;[6] ;[7]$ suggests that the strength of leadership education in the era of globalization with the competitive dynamics of the quality of a complex requires a visionary leader who can produce a wide range of the policies and operation of the working people in schools on the basis of vision, passion and dedication to work is clearly to achieve the goals of education in the school. The existence of a clear educational vision that is executed consistently by educational leaders should be supported by the cultural change that is more oriented to the quality of both the process and outcomes of education. Thus the important thing is to position themselves as educational leaders knowledgeable in the attainment of quality education in the era of globalization is to provide a strong influence on the effectiveness of educational attainment [8]; [9]; [10]. 
Referring to the above understanding, it can be interpreted that the educational leadership knowledgeable and able to transform the cultural values that exist in schools is indispensable Principal in menjalanjan tasks mandated. Many leadership models that can be adopted and applied in various educational institutions or schools, but the leadership of relevant models to be implemented in schools in the era of globalization and competitiveness that is high enough, is the learning transformative leadership. It also points out [11]; [12]; [13] that in the era of globalization and the complexity of the development of education, the role of educational leadership is not merely instructional alone, but the leader of education or a school principal should be able to act as mentors and an introduction to the transformation of experience, knowledge, and skills to the citizens of the school.

With regard to the organizational culture, the school is also an organization in a sisterm education. Several studies conducted by previous researchers about the culture of the school as a system of organizational culture that leads to an achievement of the quality of education [14]; [15]; [16]; [17] that in an education system that is in schools in which there is full of diversity and background of citizens of the existing school, then the school culture will be the peculiarities of a system of education provision that is in them, and these particularities can be a support in improving the quality of education if the school culture that can transform four things: beliefs, values, norms and standards, as well as the behavior of the residents of the existing school, especially for learners. In line with this, a quality education is not only also determined by the academic achievement of their students, but also from the aspect of character education is the internalization of a culture in schools to bring their students in the development of good character amongst the tegah dynamics advancement of age who continues to grow [18]. Thus, to achieve a good quality education needed leadership quality education, and who are able to understand the vision, mission and objectives of the school to be combined together with the internalization of the values at the school became a reference in a process of integrated education, character, and quality in the process [19].

Furthermore, school culture is a complex set of beliefs, values and traditions, ways of thinking and behaving [20]. The school culture has important elements, namely: 1) the location, environment, and the physical infrastructure of the school schoolhouse, mebelair, and other supplies; 2) The school curriculum includes ideas and facts into a whole program of education; 3) persons who are citizens of the school consisting of students, teachers and administrative staff; and 4) the moral values, regulatory systems, and climate of school life [21]; [22].

\section{B. Acculturation Character Education in the Learning Systems}

One of the key in the dynamics of the globalization of the times in the field of education, is with regard to character education. Character education is very important given to children in schools, it is that the children understand the importance of moral values of humanity and respect for the situation and environmental conditions in the dynamics of the growing progress of education. Character education is very helpful in preparing students into life in the era of globalization. "... The development of the child is viewed as simple one type of behavioral change. For the leaning theorist, intellectual development consists of an accumulation of gradual learnings, of changes in specific behaviors" [23]. The statement can be interpreted that the development of a child's behavior is influenced by the surrounding environment, and it will also affect the outlook and the concept of thinking of children against himself and the surrounding environment.

With regard to the values contained in the learning curriculum, some research conducted that the curriculum used at school- school is the curriculum should be relevant to the needs of the school, both academic interest, as well as with regard to the moral development of the children in the school were still in the rules of the values that characterize education in schools that exist in the face of education in the era of globalization [3]; [24]; [25]; [26].

Against these values, it is also stated that the value is: " $a$ belief upon which a man acts by preference. It is this a cognitive, a motor, and above all, a deeply propriate disposition" [27]. Understanding the meaning that it is the belief that human preferences used in action. Humans select or choose activities based on the value of his own beliefs. Similarly, stated that the value is abstract, because it was uncertain value contained in something. Something that contains the value (vehicles) there are four kinds, namely: exercise, behavior, attitude and basic [28].

The ability of teachers to teach character education in schools is very necessary to understand the current situation, both the students and in schools [14]; [29]; [30]; [31]; [32]; [33] This is important because with a good understanding by teachers when giving lessons at school, where in the subjects contained values of character education to be achieved, then it implies that the teacher had been giving a good understanding for students to how it should be in learning and this can be done from early childhood education. Even the results of the study confirmed that with a good understanding of character education for students, it actually has positioned the student is in equilibrium Emotional Intelligence (EI) is good [14].

Character education in the era of globalization, not only apply to students who are in the urban areas alone or in schools that have students who are heterogeneous, but also applies to all education in all areas. It's like the results of research stated that education in areas far from the city also still need to obtain and understand the importance of character education in schools [34]; [35]; [36]. However, to schools located far from urban areas, where the culture is still strong upheld as a norm of life. Then teaching character education will not be as difficult as teaching it to students in urban areas, where the mindset and plurality in everyday life may influence the development of personality and behavior of students.

Educational leadership which in this case is the principal, is also a study of the implementation of character education. It's like the results of research that as a leader of education, the principals should be able to look at the diversity of cultures 
that exist at the school, both from the students and the school environment, so that the school can position its existence on the situation and the conditions required by the needs of the students, not only in schools alone, but will be taken on a social life outside of school [37]; [32]; [38]; [39].

\section{Meaning of Values in Character Education Relate with Peace Education and Child Protection}

The advancement of education in the era of globalization is not enough to be seen from the academic quality of students produced, but it is also necessary maturity of the good character of the learner is generated, and the internalization of the values of good character education in educational institutions become indispensable so that learners can make sense academic intelligence from the perspective of cognitive and affective [40]; [41]; [42]; [43]. In a deeper study, the term "value" is not easy to be given for certain restrictions. This is due to the reality nisali an abstract [1993]. Similarly, the value is a type of confidence that is within the scope of the belief system in which a person acts or avoid an action, or of a proper or improper done. This means that to do with the meaning or meanings giving an object [45].

Values can also be interpreted as a thought (idea) or the concept of what is considered important for someone in his life [45]. Moreover, the truth of a value also does not require the existence of empirical evidence, but rather related to living and what is desired or not desired, liked or not liked by someone.

Values have two kinds of attributes, namely content and intensity. Attribute content is concerned with whether something is important. While the intensity attribute concerns the extent to which the level of importance. When we rank one's values based on the intensity, we get the value system of the person. Basically everyone has a hierarchy of values that shape his personal value system. This system can be seen through the eyes of people on the importance of values like freedom, pleasure, self-esteem, honesty, obedience, and similarity.

"A value system is a learned organization of principles and rules to help one choose between alternatives, solve conflict, and make decision." [28], it means that a value system are the principles and rules that can be learned within an organization to help someone choose among alternatives, resolve conflicts and make decisions. Further "No one has ever seen a value. Like concepts and ideas, values exist only in our minds. Values are standards of conduct, beauty, efficiency, or worth that individuals believe in and try to live up to or maintain" [46]. The statement can be interpreted that the concept of value appears by nature in a person, and it is of course, each person will have a different view, however, the main concept of value is how people put themselves on the norms prevailing in the surrounding environment.

Of the various opinions above, it is understandable that the value is a belief or trusts which is the basis for a person or group of people to choose their actions, or assess something meaningful or not meaningful for life. While the value is a ranking system based on a ranking of values of an individual in terms of intensity.

Thus, to determine or track a value must go through the meaning of the realities of another form of action, behavior, mindset and attitude of a person or group of people. The Making of a form of spiritual maturity and maturity mental function. To spiritual maturity, it is in line with that set forth namely that face a future of uncertainty, the basic steps incurred in the various communities is the effort to develop and disseminate a mental attitude of new, capable of delivering spiritual stability [47]. Meanwhile, with respect to the function of mental maturity, then assert that maturity mental function of children actually occurs through a process of cooperation with others [48].

\section{School-Based Managemet relate with Quality Improvement Education}

From the decomposition of improving the quality of education at the top of that scrutiny, the obvious importance of the role of the school as the main basis of autonomous actors, and the role of parents and communities in developing education. activity and the dynamics of education including the matter of quality of education is not first determined by the parties from outside the school, but by the schools concerned in interaction with customers.

Schools as formal education implementation unit the forefront with a wide range of diversity, different environmental conditions of the Other then the school should be dynamic and creative in performing its role to strive to increase the quality/quality of education. This will be implemented if a school with a variety of diversity that, given the trust to organize and take care of himself in accordance with the environmental conditions and needs customer.

School as an autonomous institution is given the opportunity to manage in the process coordinative to achieve educational goals [49]. The concept of these ideas have prompted the emergence of The new approach, namely the management of quality improvement for school-based education as an institution at the forefront in educational activities. That is the approach known with management to improve the quality of school-based education .

The concept of improving the quality of school-based education emerged within the framework school-based management approach. In essence, SBM will bring progress in the two areas are mutually dependent, that is, first, the progress of the program education and services to student-parents, students and community. Second, the quality work environment for all members of the organization.

To get quality like what is desired then the SBM should designed carefully, then two questions, SBM is addressed to designers when designing the quality of schools, which include: a) what we want to achieve, namely whether the end of this MBS implementation ?, and b) how achieve and what conditions relating to the achievement of objectives more mainstream? Through these two questions and then they suggested that the SBM decentralization does not mean letting schools and communities according to their way own [50]. 
Provide a comprehensive guide as a key element of reform SBM consisting of: 1) establish clear vision and the expected results, 2) creating a national objective requires focus repair, 3) the policy guidelines of the center which contains standards to school, 4) the level of strong leadership and political support and support leadership from the top, 5) institutional development (capacity building) through training and support for principals, teachers, and school board members, 6) equity in education funding or financing [47].

\section{E. Empowernment the Participation of Parents and the Community}

The most distinguishing characteristics in the concept of SBM is empowerment the participation of parents and the community. The role of parents and the community as institution is the school board or the school committee. The philosophy that became Cornerstone was that education is first and foremost in the family and the public is that development is influenced education customers by the quality of the graduates. The school has subsidier function, the primary function of education is in parents [51]. To the parents and the community need involved in the management and development of the school.

There are two-pronged approach to encourage parents and actively participate in the education community. First, the school-based approach by bringing the parents to come to school through meetings, conferences, and discussion teacherparents and visit his son who is studying in school. Second, home-based approach, that parents help their children learn in house together with teachers who visited the house [52].

While the role of the community is not only financial support, but also with keeping and creating a school environment that is safe and orderly and run social control in the implementation of education at the school. The role of public figures by becoming a mover (moving the public to participate in education), informers and liaison (informing expectations and the interests of the school community, and inform the school to community), coordinators (coordinate interests with the needs of schools business in society, for example the practice, internships, etc.).

\section{CONCLUSION}

Peace Education and Child Protection in the Central Mountains of Papua has given a lot of progress in the education sector in the regencies, especially at the level of knowledge about the rights and protection of children. Most of the community, which is a stakeholder, gave a positive appreciation it.

Child-Friendly School should established as a policy at regional level. Partnership between school, community and local government should be maintained.

Good understanding of good implementation in SchoolBased Management can reduce violence against children and improve the quality of teaching and learning in the school.

Peace education and child protection sustainability need to be escorted through advocacy for local government together with partners (leaders, community organizations or church organizations) and for further development, character education is necessary to find a model that is more practical and hands-on in accordance with the contextual of area.

\section{ACKNOWLEDGMENT}

A fellowship provided for the Philippine Institute For Development Studies (PIDS) is gratefully acknowledged. This research was also supported by the Provincial Department of Education in Papua, and also both Department of Education in the District Jayawijaya and District Lanny Jaya. The author thank to Dr. Gilbero and Dr. Lamberte from PIDS; Dr. James Modouw from Ministry of Education and Culture, Indonesia; for their support and consultation.

\section{REFERENCES}

[1] Rathgeber, T. The Rights of Economic, Social and Culture in Papua: Study of Social Reality and Politrical Perspective. Jakarta: Sinar Harapan. 2006

[2] Anderson, B. The Failure of Education in Papua's Highland, http://www.insideindonesia.org/the-failure-of-education-in-papua-shighlands. 2013. Accessed on 7 May 2016.

[3] Misco, T. Using Curriculum Deliberation to Address Controversial Issues: Developing Holocaust Education Curriculum for Latvian Schools. International Journal of Education Policy and Leadership. Vol. 2, No. 8. http://www.ijepl.org. 2007. (Online). Accessed, 16 Desember 2015.

[4] Day, C., Harris, A., Hadfield, M., Tolly, H. \& Beresford, J. Leading schools in times of change. Buckingham, UK: Open University Press. 2000 .

[5] Wagner, D.A. Improving Learning Assessments for Developing Countries. International Journal of Educational Development. www.elsevier.com/locate/ijedudev. 2013. (Online). (34) 110-111. Accessed, 14 Desember 2015.

[6] Young, M. Effective Leadership Preparation: We Know What It Looks Like and What It Can Do. Journal of Research on Leadership Education. April 2015 10: 3-10.

[7] Williams, S.M. The Future of Principal Preparation and Principal Evaluation: Reflections of the Current Policy Context for School Leaders. Journal of Research on Leadership Education. December 2015 10: 222-225.

[8] Berg, J.H., Carver, C.L., \& Mangin, M.M. Teacher Leader Model Standards:Implications for Preparation, Policy, and Practice. Journal of Research on Leadership Education. August 2014 9: 195-217.

[9] Hewitt, K.K., Davis, A.W., \& Lashley, C. Transformational and Transformative Leadership in a Research-Informed Leadership Preparation Program. Journal of Research on Leadership Education. December 2014 9: 225-253.

[10] Severson, E.D., \& DeStefano, J.B. Leadership for Transformational Learning: A Developmental Approach to Supporting Leaders' Thinking and Practice. Journal of Research on Leadership Education. August 2014 9: 113-141.

[11] Hermino, A. Educational Leadership in the Globalization Era. Jogyakarta: Pustaka Pelajar. 2014.

[12] Daryanto. Effective Learning Innovation. Bandung: Yrama Widya. 2013.

[13] Nasution, S. Various Approaches in Learning and Teaching. Jakarta: Bumi Aksara. 2010.

[14] Mayer, J.D., Salovey, P., Caruso, D.R. Emotionalle Inteligence. Theory, Findings, and Implications. http://www.calcasa.org/wpcontent/uploads/files/ei2004mayersaloveycarusotarget.pdf. (Online). International Journal of Psychological, 2004. Vol.15, No.3, 197-215. Accessed, 12 November 2015. 
[15] Bass, B.M., \& Riggio, R.E. Transformational Leadership. Second Edition. New York: Routledge. 2006.

[16] Oord, L.V. After culture: Intergroup encounters in education. Journal of Research in International Education. August 2008 7: 131-147.

[17] Winch, J. Cultural Influences in a Multicultural Academic Workplace. Journal of Language and Cultural Education. http://www.jolace.com/journal/. (Online). 2015, 3(3). DOI: 10.1515/jolace-2015-0022. Accessed, 10 November 2015.

[18] Whitaker, T., \& Gruenert, S. School Culture Rewired: How to Define, Assess, and Transform It. Arkansas: ASCD. 2015.

[19] Reeves, D.B. The Learning Leader: How To Focus School Improvement For Better Results. Arkansas: ASCD. 2006.

[20] Vembriarto, S. Socilogy of Education. Jakarta: Grasindo. 1993.

[21] Hoerr, T.R. The Art of School Leadership. Arkansas: ASCD. 2005.

[22] Kafele, B.K. The Principal 50: Critical Leadership Questions For Inspiring Schoolwide Excellence. Arkansas: ASCD. 2015.

[23] Spodek, B. Handbook of Research in Early Childhood Education. New York: Macmillan Publishing Co., Inc. 1982: 3.

[24] Peng, W.J., McNess, E., Thomas, S., Wu, X.R., Zhang, C., Li, J.Z., Tian, H.S. Emerging Perceptions of Teacher Quality and Teacher Development in China. International Journal of Educational Development. www.elsevier.com/locate/ijedudev. 2013. (Online). (34) 58-66. Accessed, 14 Desember 2015.

[25] Agrawal, T. Educational inequality in rural and urban India. International Journal of Educational Development. www.elsevier.com/locate/ijedudev. 2013. (Online). (34) 11-19. Accessed, 14 Desember 2015

[26] Mason, M. Educational inequality and educational quality. International Journal of Educational Development. www.elsevier.com/locate/ijedudev. 2013. (Online). (34) 1-2. Accessed, 14 Desember 2015

[27] Kadarusmadi. Parents Efforts in Reforming Education Situation in the Family. Unpublished Dissertation. Bandung: Postgraduate. IKIP Bandung. 1996: 5.

[28] Ndraha, T. Organizational Culture. Jakarta: Rineka Cipta. 1997: 27-28.

[29] Chan, A. 2011. Critical multiculturalism: Supporting early childhood teachers to work with diverse immigrant families. 2011.

[30] Skaalvik, E.M. \& Skaalvik, S. Teachers' Perceptions of The School Goal Structure: Relations with Teachers' Goal Orientations, Work Engagement, and Job Satisfaction. International Journal of Educational Development. www.elsevier.com/locate/ijedudev. 2013. (Online). (62) 199-209. Accessed, 14 Desember 2015

[31] Kopnina, H. Schooling the World: Exploring the critical course on sustainable development through an anthropological lens. International Journal of Educational Development. www.elsevier.com/locate/ijedudev. 2013. (Online). (62) 220-228. Accessed, 14 Desember 2015.

[32] Mills, M.K. \& Quinn, A.J. Innovation in the Teaching of Sustainability in the Business Classroom Via a Combined model of Experiental Learning, Reflective Practice and Metaphor. International Journal of Organisational Behaviour, Volume 17(3), 4-7. ISSN 1440-5377. http://www.usq.edu.au/ /media/USQ/Business-

Law/Journals/IJOB\%20Vol\%2017\%203\%20Paper\%201.ashx. 2013. (Online). Accessed, 10 November 2015.

[33] Twigg, D., Pendergast, D., Fluckiger, B., Garvis, S., Johnson, G., Robertson, J. 2013. Coaching for Early Childhood Educators: An insight into the effectiveness of an initiative. Vol. 4, No. 1, 2013, page 73. ISSN 1838-0689 online. www.education.monash.edu.au/irecejournal/. International Research in Early Childhood Education Journal. 2013. (Online). Accessed, 2 Oktober 2015.

[34] Hannum, E., Liu, J., Frongillo, E.A. 2013, Poverty, food insecurity and nutritional deprivation in rural China: Implications for children's literacy achievement. International Journal of Educational Development. www.elsevier.com/locate/ijedudev. (Online). (34) 90-97. Accessed, 14 Desember 2015
[35] Sargent, T., Kong, P., Zhang, Y. Home environment and educational transitions on the path to college in rural northwest China. International Journal of Educational Development. (Online). (34) 98-106. 2013. www.elsevier.com/locate/ijedudev. Accessed, 14 Desember 2015.

[36] Scherrer, J. The Negative Effects of Student Mobility: Mobility as a Predictor, Mobility as a Mediator. International Journal of Education Policy and Leadership. 2013. Vol. 8, No. 1. http://www.ijepl.org. (Online). Accessed, 16 Desember 2015.

[37] Shockley, K.G. Africentric Education Leadership: Theory and Practice. International Journal of Education Policy and Leadership. 2008. Vol 3, No. 3. http://www.ijepl.org. (Online). Accessed, 16 Desember 2015.

[38] Greeberg, D.N., Clair, J.A., Maclean, T.L. 2007. Enacting the Role of Management Professor: Lessons From Athena, Prometheus, and Asclepius. Journal Management Education. Vol.6, No.4, 439-457. http://jme.sagepub.com/content/21/2/155.abstract, (Online). Accessed, 14 Desember 2015

[39] Kalargyrou, V., Pescosolido, A.T., Kalargiros, E.A. Leadership Skills in Management Education. Academy of Educational Leadership $\begin{array}{llll}\text { Journal. } & 2012 . & \text { Vol.16, } & \text { No.4, 39-63. }\end{array}$ www.academicjournals.org/journal/IJSTER/article-fulltext.../6975CD22112. (Online). Diakses, 14 Desember 2015.

[40] Stromquist, N. Education in a Globalized World: The Connectivity of Economic Power, Technology, and Knowledge. New York: Rouledge. 2002.

[41] Balyer, A. Transformational Leadership Behaviors of Schoo Principals: A Qualitative Research Based on Teachers' Perceptions. International Online Journal of Educational Sciences. 2012, 4 (3), 581591.

[42] Rodriguez, F. A Community College District Chancellor's View on Transformational Leadership. Journal of Transformative Leadership and Policy Studies. Vol. 4 No. 1, June 2014

[43] Severson, E.D., \& DeStefano, J.B. Leadership for Transformational Learning: A Developmental Approach to Supporting Leaders' Thinking and Practice. Journal of Research on Leadership Education. August 2014 9: 113-141

[44] Kaswardi, E.M. 1993. Value Education Entering to the Year 2000 Jakarta: Gramedia. 1993

[45] Thoha, C. Capita Selecta of Islamic Education Kapita. Yogyakarta: Pustaka Pelajar. 1996.

[46] Welton, D.A. \& Mallan, J T. Children and Their World: Strategies for Teaching Social Studies. $2^{\text {nd }}$ Edition. Boston: Houghton Mifflin Company. 1981

[47] Soedjatmoko. Become an Educated Nation According Soedjatmoko. Jakarta: Kompas Book Publishers. 2010.

[48] Adisusilo, S.J.R. 2012. Learning Values Character. Constructivism and VCT as Affective Learning Innovation Approach. Jakarta: Rajawali Pers. 2012: 169.

[49] Hermino, A. Promoting Diversification of National Education Curriculum. Paper presented at the Symposium on National Curriculum, Hotel Mercure Ancol, Jakarta, 7 to 9 December 2015, the Ministry of Education and Culture, Republic of Indonesia (Unpublished). 2015

[50] Fullan, M. New Meaning of Educational Change. New York: Teachers College Press. 2007

[51] Rivai, V.H. \& Murni, S. Education Management. Analysis Theory and Practice. Jakarta: Rajawali Pers. 2009.

[52] Burbules, N. C., \& Torres, C. A. 2000. Globalization and education: Critical perspectives. New York: Routledge. www.education.monash.edu.au/irecejournal/. International Research in Early Childhood Education Journal. (Online). Vol. 2, No. 1, 2011, page 63. ISSN 1838-0689 online. Accessed, 22 Desember 2015 